\title{
Police Implementation of the Partial Sex Purchase Ban in England and Wales
}

\author{
Andrea Matolcsi ${ }^{1}$ (D) \\ Accepted: 10 November 2020 / Published online: 25 November 2020 \\ (C) The Author(s) 2020
}

\begin{abstract}
A main point of contention in the policy areas of prostitution and sex trafficking is whether the purchase of sex should be criminalised, whether fully (in all circumstances) or partly (only under specific circumstances). Particularly, Europe has seen several countries either fully criminalise buying sex or insofar as the person in prostitution is subject to exploitation or coercion. An example of the latter, since 2010, it is an offence in England and Wales (UK) to buy sex with a person in prostitution who has been coerced or exploited by a third party. While the offence was heavily debated before it was adopted, there has been little empirical research on its implementation, particularly by police who are on the front line of implementation. While police statistics on the offence are of questionable reliability, indications are that there has been little application of the offence. This paper explores several potential reasons for this in the context of interviews with 10 police representatives in four areas of England. Factors such as police's knowledge and awareness of the offence, difficulties with its application, and to what extent and in what way policing of prostitution and trafficking for sexual exploitation are taking place, may all be playing a role, but do not explain lack of use in all of the areas examined in this research. The notions that there are not enough victims for the law to be applied or that police may be resisting applying the offence because they find the strict liability element of the offence unfair were not supported by these interviews. This research is unique in finding that there may be an issue with police misunderstanding fundamental elements of the offence and what seems to be a lack of awareness of the offence. These findings have implications for the assessment of the enforceability of this and similar offences and policy discussions around such offences.
\end{abstract}

Keywords Prostitution · Sex work · Trafficking · Policing · Implementation

Andrea Matolcsi

andrea.matolcsi@bristol.ac.uk

1 School for Policy Studies, University of Bristol, Bristol, UK 


\section{Introduction}

There is much debate in jurisdictions around the world on how policy ought to respond to prostitution, i.e. the exchange of direct sex acts for money or other payment or benefit. Countries, states and cities vary in what activities related to prostitution - for example, selling sex, buying sex, managing/profiting from someone else's prostitution, and brothel-keepingare criminalised, if any. A central point of debate is whether buying sex acts should be banned. Some jurisdictions have offences criminalising buying sex in certain circumstances, for example in relation to street/outdoor but not indoor prostitution, buying sex with a minor, or - of relevance here - if the person from/with whom sex is bought is an adult victim of trafficking, exploitation or coercion.

The United Nations (UN) Protocol to Prevent, Suppress and Punish Trafficking in Persons, Especially Women and Children (United Nations 2000), ratified by nearly all countries in the world, obliges signatories to discourage demand for exploitation which leads to all forms of trafficking. It lists several potential ways to discourage demand, including legislation, education/training or social or cultural measures. European Union (EU) and Council of Europe anti-trafficking laws (European Parliament and European Council 2011; Council of Europe 2005), in addition to also requiring member states to discourage demand for exploitation which leads to trafficking, also oblige member states to consider (but not necessarily enact) an offence on knowingly using the 'services' of a person who has been trafficked for any purpose, including sexual, labour and organ trafficking. The European Commission (2016) has noted the importance of addressing demand for exploitation, including as posed by the 'consumer', arguing that without doing so the fight against human trafficking is less effective. They note that 'victims often have been repeatedly raped, mentally and physically abused, suffered offences against not least their freedom, dignity, sexual self-determination, bodily integrity' (European Commission 2016, 10; see also Zimmerman et al. 2006). The rationale in targeting demand is that while there are several factors contributing to the phenomenon of trafficking, including poverty, lack of opportunities and power disparities and without demand for the 'services' of victims, traffickers would not recruit them as there would be no profit to be made from their exploitation (European Commission 2016; O'Connor 2018). Around 10 EU countries have introduced offences criminalising the use of victims of all forms of trafficking, while a smaller number of jurisdictions - including England and Wales and Northern Ireland within the UK, ${ }^{2}$ the Republic of Ireland, Finland and more recently, Germany-have offences specifically criminalising the use of a victim of sexual exploitation (European Commission 2016; US Department of State 2018).

An example of the latter, the partial sex purchase ban in England and Wales was adopted with section 14 of the Policing and Crime Act 2009, which inserted section 53A on 'Paying for sexual services of a prostitute subjected to force etc' into the pre-existing Sexual Offences Act 2003. Section 53A came into force in 2010 and makes it an offence to pay for sex with a person in prostitution who is subject to coercion or exploitation by a third party (Home Office

\footnotetext{
1 'Demand' in this paper refers to the demand from individuals who buy sex. 'Demand' has also been conceptualised more widely by some to also include other actors such as brothel owners, pimps, traffickers and others who profit from the trafficking and exploitation of others, as well as state policies and societal norms (Keegan and Yonkova 2018).

${ }^{2}$ Prostitution is a devolved policy area in the UK; England and Wales, Scotland and Northern Ireland have three separate sets of legislation around it.
} 
2010; Crown Prosecution Service 2018). This covers situations of both trafficking and 'pimping', and all locations including indoor (e.g. brothel, escorting) and street/outdoor prostitution. EU and Council of Europe law recommend, and other European countries with such offences contain, the requirement that the buyer had or ought to have had knowledge that the person with whom they are buying sex is a victim of trafficking or exploitation. Uniquely, with section 53A it is irrelevant whether the buyer was or ought to have been aware of the exploitation; it is a strict liability offence.

Across Europe, the implementation and impact of offences partly criminalising buying sex are being evaluated and scrutinised (European Commission 2016; Niemi and Aaltonen 2014; O'Connor 2018). Meanwhile, other European countries, such as the Netherlands (Government of the Netherlands 2013), have been discussing their introduction. These discussions around partly criminalising buying sex are inextricably linked to debates on fully criminalising sex under all circumstances, not only if the person with whom sex is bought has been coerced or exploited by a third party - particularly in conjunction with decriminalising the sale of sex and providing support and services to people selling sex, an approach known as the Swedish or Nordic Model. Northern Ireland in the UK and the Republic of Ireland, after much debate, have both fully criminalised the purchase of sex after experimenting with partial sex purchase bans. An EU-funded study carried out by NGOs (O'Connor 2018) comparing demand legislation in six EU member states concluded that among those countries, laws criminalising buying sex 'only where there is proof the person is a victim of trafficking or procuring is inoperable from an enforcement point of view and ineffective in relation to the wider goal of acting as a deterrent and reducing demand' (29). The study authors argue instead for fully criminalising buying sex. Another study (Keegan and Yonkova 2018) with buyers in four EU countries concluded that offences against buying sex from a victim of trafficking or exploitation do not deter buyers from doing so. Most of the buyers participating in their study were found to assume that the person they are buying sex with is consenting and did not appear to make meaningful efforts to distinguish between coerced and voluntary, even if they have previously witnessed or suspected exploitation. The authors argue that there is no separate, distinct sex market for individuals who have been trafficked (Keegan and Yonkova 2018; see also O'Connor 2018) and that a full sex purchase ban would be more effective.

Section 53A itself was proposed after a full sex purchase ban was discussed in the UK parliament but decided against (Mulvihill 2014; Home Office 2008). The policy debate around whether it should be replaced by an offence fully criminalising buying sex has been ongoing (APPG 2014; 2018; HASC 2016). Among those who have concluded that section 53A is seeing little application, some (APPG 2014; Niemi and Aaltonen 2014) have recommended extending the offence to fully criminalise buying sex, suggesting this would make it easier to implement and, therefore, more effective. Meanwhile, others (Kingston and Thomas 2014) question whether the offence can ever be effective, and as discussed below, whether it is warranted at all. Indeed, there is also a movement strongly opposing the Swedish or Nordic Model, and instead arguing for legalisation or decriminalisation of prostitution, as found for example in Germany and New Zealand, respectively.

In the context of these discussions and debates on partial sex purchase bans England and Wales and wider Europe, this paper provides further insight into the implementation of one such offence, section 53A in England and Wales. It focuses on police as those on the frontline of implementation, playing a crucial role in identifying victims and deciding whether an 
offence appears to have taken place and needs to be investigated (Grubb and Bennett 2012; Hester and Lilley 2017). It expands on previous research by critically examining potential reasons for its seeming lack of use, using interviews from a wider geographic spread across England. This paper focuses on implementation and does not seek to assess the effectiveness or impact of the offence.

\section{Previous research}

There tends to be a greater interest in the development of prostitution policy as opposed to its implementation (Wagenaar and Altink 2012). In line with this, while there was much discussion among lawmakers (Mulvihill 2014, 2015), academics (Brooks-Gordon 2010; Kingston 2010; Munro 2010; Carline 2011a, b, 2012; Munro and Scoular 2012; Keren-Paz and Levenkron 2009) and activists about section 53A before it was adopted, focusing on its appropriateness and whether it should be adopted (Matolcsi 2017), there has been much less discussion about section 53A since it came into force in 2010, and little empirical research on its implementation. A small handful of studies (Bindel et al. 2013; Kingston and Thomas 2014; Niemi and Aaltonen 2014) and an inquiry report by a parliamentary grouping of MPs (APPG 2014) provide empirical information on the implementation of section 53A. Their findings are set out below.

\section{Extent of application}

The few existing studies (Bindel et al. 2013; Kingston and Thomas 2014; Niemi and Aaltonen 2014) and parliamentary inquiry (APPG 2014) discussing implementation have concluded that there appears to have been little application of section 53A. The wider research of which the interviews presented here were part (Matolcsi 2017) included an examination of publicly available data, as well as the collection and analysis of criminal statistics obtained through Freedom of Information requests made by the author in October 2014 to all police forces in England and Wales and the Home Office requesting police-level data, as well as Crown Prosecution Service (CPS) and Ministry of Justice for prosecution and conviction figures. Unlike previous studies, it found there to be significant shortcomings with criminal statistics on the offence, particularly police-recorded crime. This includes inconsistencies between figures, incorrect data provided by agencies and what appears in several cases to be confusion between section 53A and section 51A of the Sexual Offences Act 2003 on soliciting to buy sex in a public place (also known as 'kerb crawling'). It is argued that these shortcomings make it impossible to know with certainty when and where the offence has been used by police (and also put into question the reliability of data obtained from police previous research; e.g. Kingston and Thomas 2014). However, as discussed later, this study also suggests little application of the offence by police. In terms of prosecutions, there have been few (66) reported under the offence since it came into force in 2010 until 2019 (Crown Prosecution Service 2017, 2019). While prosecution figures appear more reliable than police figures, one government report (Her Majesty's Government 2011) notes that the 40 prosecutions reported under the offence in 2010-2011, by far the highest reported number in all years it has been in force, included cases of 'kerb crawling', i.e. soliciting to buy sex in a public place, which is a separate offence. The report does not elaborate on how or why cases of kerb crawling have been included in this figure. This leaves confusion around precisely how many prosecutions 
were made under section 53A. Conviction figures - which are more consistent than both police and prosecution figures - indicate there have been just 63 convictions under the offence between 2010 and 2016 (UK Ministry of Justice 2018).

\section{Knowledge and awareness}

An issue raised in relation to section 53A has been a lack of understanding among criminal justice professionals, including police, about the offence. No resources were allocated at the national level for training on the offence, although some local authorities have provided training independently for their staff (Niemi and Aaltonen 2014). A lack of training and inadequate understanding of among criminal justice practitioners in the UK of prostitution and human trafficking, and applicable offences, is an issue that has been identified by researchers looking at section 53A (Niemi and Aaltonen 2014; Bindel et al. 2013) and at prostitution and trafficking broadly (Kelly and Regan 2000; Annison 2013; Brayley and Cockbain 2014).

\section{Difficulties with enforcement}

Criminal justice practitioners, particularly police, have reported difficulties with applying section 53A (Niemi and Aaltonen 2014; APPG 2014). They have argued that, in light of strict evidentiary requirements, coercion of the person in prostitution is too difficult to prove; this includes both overt, physical coercion and even more so when it is a more subtle or gradual process (APPG 2014). Proving coercion and exploitation is an oft-cited difficulty in relation to trafficking or exploitation in prostitution (Kelly and Regan 2000; Hoyle et al. 2011; Annison 2013; Renzetti et al. 2015; Walby et al. 2016). Obtaining the cooperation of a victim/survivor in investigations and prosecutions against their exploiters is challenging. They may fear repercussions from the exploiters/traffickers, suffer from trauma, fear criminalisation (for example for engaging in prostitution), fear deportation if they have irregular migration status, feel they will not be believed and/or feel a sense of shame (Walby et al. 2016; Hoyle et al. 2011; Annison 2013; Kelly and Regan 2000; Renzetti et al. 2015; N Westmarland 2006). Regarding trauma, victims of sex trafficking and exploitation can suffer severe mental, physical and sexual violence and harms (Walby et al. 2016; Kelly et al. 2009). This can hinder cooperation with authorities, particularly if they do not receive adequate support (Walby et al. 2016; Annison 2013; Hoyle et al. 2011). All this can make it difficult for victims to present as such, or disclose to or cooperate with police and other authorities, and if they do it can take a long time (Annison 2013; Hoyle et al. 2011). With foreign victims, there may also be language barriers and difficulties with using interpreters, which can result in lost or misunderstood information (Annison 2013). Compounding these issues can be practitioners - in part due to a lack of understanding as discussed earlier — not identifying victims of trafficking or exploitation in prostitution in the first place, or not treating them as victims, for example if they are in the country illegally and/or because selling sex is criminalised in their jurisdiction. Police and other agencies can sometimes not view victims as 'worthy' of assistance if they have not experienced brutal physical violence or overt coercion, if they have returned to their traffickers after being assisted in the past or because they are viewed simply as sex workers who have made a choice to be in prostitution (L Westmarland 2009; Hoyle et al. 2011; Farrell et al. 2015; Jones and Kingshott 2016). Meanwhile, the CPS is more likely to prosecute a case, a jury more likely to convict and a more serious sentence be imposed on the traffickers/exploiters, if the victim testifies (Annison 2013). 
In addition to these difficulties on the victim side, police in some areas of the UK have reported difficulties obtaining intelligence on, and enforcing against, individuals controlling or coercing someone else's prostitution for gain ('pimps') (APPG 2014). A further difficulty predicted to be an issue with section 53A before its adoption was finding resources to apply the offence, particularly if interpreting it broadly to include less overt forms of coercion (Munro 2010). No resources were allocated at the national level to assist with the enforcement of the offence (Niemi and Aaltonen 2014). Some also argued that criminal justice practitioners might resist enforcement because of the above-mentioned difficulties (Mulvihill 2014, 2015). Ultimately, where street prostitution is implicated and section 53A may be applicable, practitioners have voiced that it is considered easier to apply the offence soliciting in a public place because it does not require proof that the person in prostitution has been subject to exploitative conduct (Niemi and Aaltonen 2014).

\section{Policing approach}

Prostitution is not a priority for most police forces in the UK (Kelly and Regan 2000; Matthews 2008; Annison 2013). If police do carry out work in this area, their focus does not tend to be on buyers (Kelly and Regan 2000; Hoyle et al. 2011; Niemi and Aaltonen 2014). If they do target demand, they will usually focus on buyers of street/outdoor prostitution, against whom - as noted - the offence on soliciting to buy sex in a public space has been voiced by some as easier to apply (Niemi and Aaltonen 2014). It has therefore been suggested that a lack of use of section 53A may be due to many police forces not dealing much or proactively with prostitution and/or not targeting buyers (Niemi and Aaltonen 2014). While this may be the case in some areas, research with one London borough (Bindel et al. 2013) showed that carrying out significant work around prostitution, and within that taking a demand-reduction approach and targeting buyers, does not necessarily mean that a police force or unit applies section 53A (Bindel et al. 2013) — as the present study also found. It has furthermore been posited that police may be reluctant to use section 53A because it positions people in prostitution as victims, while - as discussed earlier - they may view them as offenders (Kingston and Thomas 2014). National, non-binding guidance for police on prostitution calls on officers to not treat people selling sex as criminals solely for selling sex, to refrain from enforcing against them, to treat them as vulnerable and seek to improve their safety, and to target those who exploit or cause harm to those selling sex (National Police Chiefs' Council 2019). However, this guidance is nonbinding, and the 44 police forces across England and Wales take varying approaches to how - and indeed whether - they police prostitution.

\section{Strict liability element}

The fairness or unfairness of the strict liability element of section $53 \mathrm{~A}$-which makes it irrelevant whether the buyer knew or ought to have known that the person with whom they were buying sex was coerced or exploited by a third party - was a large part of the debate on section 53A before it was adopted (Mulvihill 2014, 2015). Some argued that criminal justice practitioners might resist enforcement not only because of the real or expected difficulties described above but also because they considered the strict liability element unfair, as even if a buyer asks the person in prostitution if they are being exploited, they would likely be told 'no' (Mulvihill 2014, 2015). Since the offence came into force, some practitioners have expressed negative views on the strict liability element, but not because they considered it unfair; rather, 
they felt that, had it not been included, the punishment under the offence could have been greater than the current maximum $£ 1000$ fine (Niemi and Aaltonen 2014).

\section{Not enough victims?}

Finally, Kingston and Thomas (2014) conclude that hardly any police forces have used section $53 \mathrm{~A}$ and raise the possibility that the scale of trafficking and sexual exploitation has been exaggerated and there might simply not be that many individuals in prostitution who are subjected to force, deception or threats by a third party. In this scenario, section 53A is not being used because there are not enough victims in relation to whom it could be applied.

The above are some of the issues raised with section 53A which may be affecting its implementation, which will be examined in this paper. Comparison with similar partial sex purchase bans in other jurisdictions is difficult given variations in, for example, wider legal frameworks, cultural attitudes, and the make-up and histories of policing. However, in order to provide some context, other partial sex purchase bans in other European countries have also seen low levels of application, including the similar (but different in requiring the buyer's knowledge of the exploitation) offences in Finland (Niemi and Aaltonen 2014; O'Connor 2018) and the Republic of Ireland (O'Connor 2018), and the strict liability offence identical to section 53A which existed in Northern Ireland (Great Britain, Northern Ireland Assembly Hansard 2013) until it was replaced by a full sex purchase ban in 2015. Many of the issues with implementation described here in relation to section $53 \mathrm{~A}$ - in particular difficulties obtaining victim cooperation, the resource-intensive nature of investigating exploitation in prostitution and sex trafficking, some criminal justice practitioners lacking adequate knowledge of the offences they are tasked with enforcing and a lack of police investigations into sex buyershave also been identified elsewhere (Niemi and Aaltonen 2014; Great Britain, Northern Ireland Assembly Hansard 2013). As noted, unlike the partial sex purchase bans in England and Wales and Northern Ireland, most existing partial sex purchase bans in other countries require proof that the buyer was aware of the exploited or trafficked status of the person with whom they bought or attempted to buy sex. This has been found to be a major hurdle in the application such offences, with buyers often successfully claiming that they did not or could not have known about the exploitation (Niemi and Aaltonen 2014; European Commission 2016).

\section{Methods}

Previous empirical evidence on section 53A has been largely limited to the city of London (Niemi and Aaltonen 2014; Bindel et al. 2013) or to practitioners who chose to respond to a public inquiry (APPG 2014). Or, they present criminal statistics but without qualitative data to help explain them (Kingston and Thomas 2014). As part of the wider study into the implementation of section 53A (Matolcsi 2017) of which the analysis presented here forms part, interviews were carried out with 21 participants, consisting of 10 police, 9 service providers and 2 local authority representatives, in four locations in England. The four locations varied in terms of demographics and the size of police forces. All police participants specialised in prostitution and/or sex trafficking, with most currently or formerly belonging to specialist units in these fields, while others were designated officers responsible for the topic(s) within their force. Interviews were transcribed verbatim, and the Framework approach to qualitative data (Ritchie et al. 2014) was used to carry out a thematic analysis with the aid of qualitative 
analysis software NVivo. Themes were drawn from the existing literature on section 53A and on the policing and implementation of other prostitution and sex trafficking offences, and emerging themes raised by interview participants were added. Participants and their locations are anonymised. Due to the limited sample size and the specificities of local contexts, these findings are not generalisable to England and Wales as a whole. Ethical approval for this study was obtained from the University of Bristol.

\section{Results: Factors which may be affecting implementation}

The following sections present findings from the 10 police interviews conducted for this research, which focused on their experiences and views on implementation of section 53A. Before discussing selected factors which may be affecting implementation, the following section describes participants' statements concerning the extent of application of the offence.

\section{Extent of application}

Of the 10 police participants interviewed for this research, only one had used section 53A themselves. This was on one occasion, as part of a brothel operation in 2010 (the year the offence came into force), with a small handful of individuals arrested. The participant was not aware of the offence having otherwise been used in their force area. The other nine officers were not aware of the offence having been used in their force areas. Two officers indicated that they had attempted to apply it. Participant views on section 53A were therefore informed by either having used or tried to use it $(n=3)$, and/or in most cases $(n=7)$ their broader-in most cases extensive-experience of policing prostitution and/or sex trafficking. While these interviews were limited to four police force areas, several participants had knowledge at the national level and would likely have been aware had the offence been used elsewhere.

\section{Knowledge and awareness}

Several participants felt that police in general have little knowledge of section 53A, and of prostitution and sex trafficking broadly. They noted that there had been little to no training on section 53A in their units or wider forces, nor on prostitution/trafficking generally. Indeed, of the ten police participants in this research, only two displayed both awareness and significant knowledge of the offence, including awareness that it is a strict liability offence, that it can be used both in relation to indoor and outdoor prostitution and/or citing the fine level associated with the offence. The remaining officers were either aware of the offence but did not display significant knowledge of it $(n=5)$, for example inaccurately discussing aspects of it, or they appeared to have very little knowledge or in some cases, even awareness of the offence $(n=3)$, for example first studying the text of the offence at the interview. Several police participants misunderstood the strict liability element, believing it needs to be proved that the buyer was aware of the exploitation or coercion of the person in prostitution:

How on earth would I know whether (...) the person I'm having sex with, has actually been subjected to coercion (...)? (Police participant 2)

It's very difficult to police. (...) Because you have to...there's the element, isn't there, of the person has to know the girl was trafficked? (Police participant 6) 
Some participants pointed to the low level of awareness and knowledge of section 53A, and of prostitution and sex trafficking generally, as a possible reason behind its apparent lack of use:

I think it could be a very good piece of legislation, and I don't really know why it's not used as much, other than people don't know enough about it, is perhaps a reason. (Police participant 3)

While the focus of this paper is on police, the view of one NGO participant who contributed to the wider interviews is of note. This participant, who works with victims of trafficking and extensively with police, felt that police misunderstanding the offence may be a barrier to their using it:

So it's interesting that you said that what you don't have to prove is that the purchaser, in quotes, did everything to ensure that the person wasn't in an exploited situation, i.e. asked, investigated or whatever. But I think that's the general understanding of the legislation, and that could be part of the problem (...) It's a perceived barrier, in terms of, how do you prove that. (Service provider 3)

A lack of awareness or knowledge of section 53A may certainly be a factor in its apparent lack of use, at least in some locations and among some police officers. However, in the four areas examined, even where police and other practitioners displayed awareness and knowledge of the offence, they reported little or no use. Furthermore, three of the force areas examined included section 53A in local trainings, and some participants described how they had been encouraging colleagues to apply it, both of which should increase awareness and knowledge of the offence among police in those forces or specialist units. However, these participants were not aware of the offence being used in their areas. Thus, while not knowing about section 53A, or misunderstanding it, may certainly be a reason why some police do not use the offence, this does not explain lack of use in all of the areas examined here.

\section{Difficulties with enforcement: Real and perceived}

Police participants described what they feel to be numerous difficulties with using the offence. A main issue raised was establishing, investigating and proving that the person in prostitution has been coerced or exploited. According to the police participant who has used the offence:

The caveat of subject to force, exploitation etc. etc., makes it very difficult to prove (...). by putting those caveats on it, it made it a very difficult offence to actually use. (Police participant 8)

Participants discussed how victims of trafficking or pimping often do not present as such to police or other services, do not report coercion or exploitation or do not cooperate with investigations or prosecutions - and if they do, gaining their trust and cooperation can take months or even years:

Generally speaking, I suppose, [the victim] would have to be the key witness. And (...) that's difficult, isn't it. It's rare for victims of trafficking, slavery to put their hands up and say, you know, I've been exploited, come and help me. Let alone, that person there paid me to engage in sex. (Police participant 2)

Victims' reluctance to disclose or cooperate with police or other services were described as being for several reasons, including trauma, shame, intimidation by controllers, mistrust of the 
police and not recognising themselves as coerced or exploited. Regarding the latter, some participants discussed how the psychological control that traffickers and pimps can have over victims, as well as previous experiences of exploitation and abuse, can prevent individuals from seeing their situation as exploitative or coerced:

(...) you're going right back. If you're mugged or your car's nicked, you know. Some of these girls don't even know they're trafficked. (Police participant 6)

In addition to these barriers on the part of victims which can hinder their identification, disclosure or cooperation, some participants felt that police often do not have adequate knowledge of trafficking or exploitation to be able to recognise victims in the first place:

The other big issue for us is that understanding of the issue. So the example of [local units] dealing with [prostitution] as anti-social behaviour. Well that's fine, because that may address the issue, but you need to realise that you've got a potential victim of trafficking. And unless you're aware or attuned to that, there are clear points where there is an opportunity for intervention, and to remove someone who could be extremely vulnerable, where they're just dismissed as being a sex worker. (Police participant 9)

Another key difficulty raised was in relation to the buyer side of the offence. First, the fact that victim cooperation is difficult and can take a long time makes it difficult to investigate buyers who may have paid for sex with them. In relation to indoor prostitution, participants pointed out that if victims do disclose, it is often away from the brothel or other premises, when police are no longer around the buyers:

(...) when we've gone in that first time, it's not then they've said they're a victim. So it might take us 5-6 visits with them before they come forward and say they're a victim. And usually, you've come far away from the brothel. So there's not gonna be a client there. (Police participant 4)

When asked about investigating buyers previously identified during street patrols or brothel checks after a victim has disclosed exploitation or coercion, police participants were reluctant, citing limited resources and other priorities. Some police participants furthermore stated that it is difficult to prove that men bought or attempted to buy sex. Finally, as discussed, some harboured the perceived - but not actual — difficulty of having to prove that the buyer knew of the exploitation or coercion, which is not necessary with section 53A.

Further difficulties raised by police participants included limited resources and the resourceand time-intensive nature of investigating coercion and exploitation in prostitution:

So it's a lot of time, money, effort. (Police participant 2)

Further difficulties raised were high requirements from the CPS for evidence, with some participants lamenting that they have put cases forward for prosecution but the CPS refused; that prostitution and sex trafficking are 'hidden', which makes trafficking '(...) very difficult to uncover, very difficult to investigate, and difficult to prove' (Police participant 2); the difficulty of investigating online escort agencies because there is no static location to observe; that brothels have become more covert and difficult to find; the difficulty of gaining the cooperation of hotels (where victims can be exploited); and pressure placed on the police to refrain from investigating brothels by groups advocating for a hands-off approach to prostitution. 


\section{Policing approach}

Several police participants felt their areas - whether force-wide or local divisions - do not carry out an adequate amount of policing around prostitution and sex trafficking, particularly by officers in local divisions who may have less specialist knowledge and resources or have other priorities. One participant noted that, in their city, police have a hands-off approach to prostitution, meaning they do not deal with it unless they receive significant complaints from residents. In their view, this has resulted in police having little awareness of relevant offences, and therefore not applying them:

(...) we're not doing anything that resembles that kind of intensive activity. So, that would explain why we have probably not great knowledge of, and certainly very little use of, new legislation. (Police participant 3)

A view held by several participants was that, even in areas that had previously targeted buyers, the main focus has since been on traffickers and, to a lesser extent, those controlling prostitution for gain, as well as ensuring the safety and welfare of people in prostitution and potential victims:

I think the emphasis of law enforcement at the moment is, to firstly, safeguard any victims, and secondly, prosecute any of the traffickers and exploiters. We'd be much less interested in someone who came along and paid for it. (Police participant 2)

Several participants thus made a link between their area's extent of and approach to policing prostitution and sex trafficking on the one hand, and lack of use of section 53A on the other. Indeed, in the one study location in which participants reported using it, this was by a specialist unit which was at the time carrying out intensive work on sexual exploitation, and was targeting demand (in addition to assisting victims and investigating controllers). However, several of the other areas examined had also carried out significant policing around prostitution or sex trafficking or both, with some also targeting buyers, but participants from these areas were not aware of section 53A having been used. Thus, while it may play a role in some locations, carrying out significant policing around prostitution or sex trafficking, even if targeting buyers, does not appear to necessarily translate into section 53A being used.

\section{Strict liability element}

As noted, several participants did not seem aware that section 53A is a strict liability offence. Among those who discussed this element correctly, several viewed it favourably:

See, the good thing is, it doesn't matter, does it, it's irrelevant whether they're aware. (Police participant 4)

One participant felt the strict liability element helped make section 53A more of a deterrent when they tell buyers about it:

(...) it does not matter, and we do tell them, if you've asked that woman and she says 'I'm fine', and she looked lovely and she was happy and smiley, it's an offence and you would be convicted of it, because it's absolute. So we try and get that message across. (Police participant 1) 
Others felt more ambivalent about it. Some expressed that they did not want to 'tar all men with the same brush', since - they argued — some men would not have sex with a woman in prostitution if they were aware she did not want to have sex with them. Several participants, some while understanding that section $53 \mathrm{~A}$ is a strict liability offence, differentiated between buyers knowing or not about the coercion or exploitation, viewing the former as more serious, and suggesting that the punishment should be lower in cases where the buyer did not know. While participants held nuanced views on the strict liability element, none appeared to regard it negatively enough to prevent them using the offence. Indeed, the fact that several did not seem aware of it suggests this is not something holding many of them back.

\section{Not enough victims?}

As noted, it has been suggested (Kingston and Thomas 2014) that one reason section 53A is not being used may be that the scale of exploitation and trafficking in the sex industry is not significant enough - i.e. there are not enough victims for it to be used. This was not the view held by the participants in this research.

Two police participants expressed the view that while they feel exploitation is present, it is difficult to know the true scale, not least because it is relatively hidden and victims can be difficult to identify. One participant simultaneously expressed somewhat contradictory views: on the one hand, they opined that many foreign individuals claiming to be victims of trafficking are only doing so in order to be able to remain in the UK. At the same time, they stated that there are likely to be many victims who remain undetected and that the true scale of exploitation is probably larger than is known. The remaining seven participants felt that in their areas and/or nationally, there is a significant amount of exploitation in prostitution, including trafficking and pimping:

The amount of exploitation that's going on, the amount of females that are working, the amount of brothel premises, (...) it's terrible, it's exploitation. (...) So, it's just huge, and then you know, that's even without touching the online, escort agencies. (Police participant 8)

All police participants discussed exploitation taking place locally, and in relation to both on-street and indoor prostitution, of both British and non-British victims, perpetrated by individuals and organised crime groups. They described various forms of coercion, including deceit, debt bondage, threats, intimidation, physical violence and psychological control. Some noted that, in their areas, many people in prostitution-whom they described as being overwhelmingly women - are disadvantaged, for example coming from a care background, having suffered sexual abuse as a child and/or suffering from a drug or alcohol addiction, with all these being factors which made them more vulnerable to exploitation.

When participants were asked whether they agree with the notion that an offence such as section 53A is not warranted because the scale of exploitation and trafficking in prostitution is not extensive enough, the majority disagreed:

Definitely not. You know, I've said for years, if we concentrate on it, we could rescue somebody every day. And (...) now we've started concentrating on it, there's victim after victim after victim coming across. And that's spending the time, they're coming forward now. So I don't think that's an argument. (Police participant 4) 
Police participants therefore largely felt that an offence like section 53A is warranted given the scale of exploitation in prostitution as they perceive it. It should be noted that this did not necessarily translate into support for section 53A specifically. As discussed, some felt the offence is difficult to use or that many police officers may not be aware of it. Some also expressed the view that it is ineffective for various other reasons, including buyers and the general public not being aware of it, or because the punishment - a maximum fine of $£ 1000$ and no possibility of prison-is too low.

\section{Discussion and conclusions}

While criminal statistics, particularly from police, on section 53A are of questionable reliability (Matolcsi 2017), this research supports previous conclusions (Niemi and Aaltonen 2014; Kingston and Thomas 2014; APPG 2014; Bindel et al. 2013) that there has been little use of the partial sex purchase ban in England and Wales since it came into force in 2010. This paper has examined some possible reasons for this.

Several participants in the areas examined displayed a low level of knowledge and awareness of the offence, something not been identified by previous research and which can arguably be traced back to shortcomings in police training. While a lack of knowledge and awareness may be a reason in some areas for lack of use of the offence, some locations examined here have seen little to no use of the offence even by police who are very aware and knowledgeable about it. Similarly, while police not carrying out significant work on prostitution or trafficking, or not targeting buyers of sex, may explain lack of use in some areas, some of the locations in this research saw little to no use even by areas where police carry out significant work and otherwise target buyers of sex. Related to policing approach, the notion that some police may not enforce section 53A because they do not consider individuals exploited in prostitution to be victims (Kingston and Thomas 2014) is not something that was directly explored during these interviews. However, participants on the whole did not express such views and rather described people in prostitution as, at a minimum, highly vulnerable.

The difficulties discussed around applying the offence may indeed be holding some police back, as some predicted before its adoption (Mulvihill 2014, 2015). This may particularly be the case if police have attempted to apply the offence but have failed to obtain prosecutions or convictions, something found to be discouraging practitioners in relation to the partial sex purchase ban in Finland (Niemi and Aaltonen 2014). It is notable however, and not identified by previous research, that one of the first 'difficulties' cited by several participants in this study is needing to prove the buyer's knowledge of coercion or exploitation, which is not in fact necessary with section $53 \mathrm{~A}$ being a strict liability offence.

The fact that section 53A does not require the buyer's knowledge of exploitation to be proved - a noted difficulty with similar offences in some EU countries (Niemi and Aaltonen 2014; European Commission 2016) - should, in theory, make this offence easier to use. However, including the strict liability element in section 53A does not appear to have made it more likely to be applied than offences which do require knowledge. This may be because there are other factors at play, including difficulties around the need to prove coercion and exploitation.

Several of the difficulties discussed here have been identified with other offences criminalising the use of services of victims of trafficking for sexual and other types of 
exploitation (Great Britain, Northern Ireland Assembly Hansard 2013; Niemi and Aaltonen 2014; European Commission 2016). However, the European Commission and Council of Europe (European Commission 2016) argue that such difficulties arise with numerous other types of laws, many are not insurmountable and they are not a reason to not pursue such perpetrators of such offences.

The suggestion that there are not enough victims for the offence to be used (Kingston and Thomas 2014) was not supported by these interviews. Nor is it supported by national statistics: The number of individuals trafficked into and within the UK is contested and impossible to accurately know. However, in 2019, 1645 adults (of which 1481, or 90\% were women) were referred by police, NGOs and other 'first responders' to the national mechanism used to identify victims of trafficking as potential victims of sexual exploitation within and into the UK (Home Office 2019). Some referred potential victims are ultimately deemed by the authorities each year not to have been trafficked (the legitimacy of these decisions has been questioned by victim support services). However, there will also be a number of cases that are not referred into the system, for example because the victim chooses not to be, or if the victim is not detected in the first place (see also O'Connor 2018). As such, these figures most likely represent estimates of minimum numbers of victims of trafficking for sexual exploitation in the UK. Furthermore, individuals who do not fit the legal definition of trafficking, but are exploited or coerced by a third party, will not be counted in these figures at all. Ultimately, the proposition that there are hardly any victims of sexual exploitation in the UK, and that this is why there appears to be very little use of an offence targeting those who buy sex with them, is not well supported.

These findings are limited to four police forces in England and ten police officers. Further research with more criminal justice practitioners-including at the prosecution and court levels, as well as with support organisations working with men and not only women in prostitution - in more areas of England and also in Wales, would help to better understand the implementation - or lack thereof — of the offence. Further research can also explore other factors potentially affecting implementation, such as changes in national governments and policies on prostitution and trafficking (Niemi and Aaltonen 2014; Matolcsi 2017). Comparative research could be carried out with partial sex purchase bans in other jurisdictions, while remaining mindful of differences in local contexts. Any research should bear in mind potential limitations of statutory and NGO data. In England and Wales, this currently includes shortcomings with the way police collect, store and provide criminal statistics, including through Freedom of Information requests (Matolcsi 2017; Simmons et al. 2003; Her Majesty's Government and College of Policing 2013; ONS 2014; HMIC 2014; Public Administration Select Committee 2014; Independent Anti-Slavery Commissioner 2015; Westmarland et al. 2018).

These findings can be taken into consideration when further evaluating the implementation of this offence, and - while each national context is unique — of similar offences. In particular, when looking at how an offence is being applied, it should be examined whether police have received adequate training on the offence; whether they are aware that it is an offence they could be implementing; and what they consider to be difficulties with enforcement, and whether these difficulties are real or perceived. It may be that there are real hindrances rooted in, for example, the wording of this and similar offences, or the nature of prostitution and sex trafficking, which prevent the offence being used. However, any potential issues with application must be critically examined. Furthermore, such issues with implementation must be looked at before — or as part of — any evaluation of an offence's impact. 
That section 53A appears to have been seldom used lines up with little application of the identical partial sex purchase ban in Northern Ireland (Great Britain, Northern Ireland Assembly Hansard 2013) while it was in force, and similar offences in Finland (Niemi and Aaltonen 2014) and the Republic of Ireland (O'Connor 2018). There has also been little use of offences in European countries criminalising the use of 'services' of victims of all forms of trafficking (European Commission 2016). The European Commission (2016) has argued that little use does not necessarily mean an offence is ineffective, as its main purpose is to deter the crime from taking place in the first place. That said, in countries where such offences are part of government efforts to reduce trafficking and exploitation, policymakers should be aware of, and address, potential issues that may be affecting their implementation.

Countries are obligated under international and, for member states of the European Union and/or Council of Europe, European law, to discourage the demand that fosters exploitation which leads to trafficking. If a jurisdiction's avenue for doing so in relation to sex trafficking is the partial criminalisation of the purchase of sex, they should ensure that such offences are implemented. This includes making sure that criminal justice practitioners - including police, prosecutors and judges - have the knowledge, resources and support necessary to do so, and that the public is aware of the offence. However, if significant training and resources have been put into the implementation of partial sex purchase bans and the assessment remains that they are not being used or are not having a significant impact, as this and other research (Niemi and Aaltonen 2014; O'Connor 2018; Keegan and Yonkova 2018) suggest, governments should consider fully criminalising the purchase of sex-while also decriminalising its sale and providing support and services to those in prostitution, as already done by Sweden, Norway, Iceland, France, Israel, and, after experimenting with partial criminalisation of buying sex, Northern Ireland and the Republic of Ireland. This approach has been argued to be more clearcut and easy to enforce than partial criminalisation (Niemi and Aaltonen 2014; O'Connor 2018), as a result more effectively reducing human trafficking as well as gender, class and other equalities (Ekberg 2004; Waltman 2011; Coy 2012; O’Connor 2018). Indeed, the one police participant in this study who successfully applied the offence felt thus:

So to me, my own personal view, is that if you're gonna bring it in, bring it in, and say that it is an offence to pay for sexual services of somebody. That's it. Don't then put that caveat on it that makes it more difficult to prove and brings other things into play. (...) I think you either have nothing, or you have that, as opposed to something in the middle, which can't really be used. (...) I can't see why you wouldn't. The amount of exploitation that's going on (...), it's terrible (...). Well then, deal with the demand, (...) try and get more of a deterrent against people that are actually paying for these services, and then you might actually get somewhere. (Police participant 8 )

Fully criminalising buying sex has been endorsed by the Council of Europe Parliamentary Assembly (2014) as 'the most effective tool for preventing and combating trafficking in human beings'. Criminalising buying sex, and the way existing sex purchase bans are implemented, is not without its critics (see e.g. Kingston and Thomas 2019; Brooks-Gordon 2005; Sanders 2008), including some of the NGO participants in this wider study who would prefer the full decriminalisation or legalisation of selling and buying sex and other activities associated with prostitution. However, if not through the partial or full criminalisation of the purchase of sex, jurisdictions must find another way fulfil their legal obligation to reduce the demand for trafficking for sexual exploitation, not least in light of the physical, sexual and emotional violence and trauma experienced by victims of trafficking for sexual exploitation (Zimmerman 
et al. 2006). If they have not already done so, they should also decriminalise its sale and ensure that services are provided to people selling sex, including to find another means of income for those who wish to stop selling sex, while criminalising profiting from the prostitution of others - policies endorsed by the parliaments of the EU and Council of Europe (European Parliament 2014; Parliamentary Assembly of the Council of Europe 2014).

Acknowledgements I am grateful to Professor Marianne Hester and Dr. Geetanjali Gangoli for their supervision and guidance of this research, Dr. Natasha Mulvihill for her thorough review of numerous drafts of this paper and Brendan Wynne and Alan Caton for their comments on drafts. I would like to thank the anonymous peer reviewers who provided thorough and helpful feedback on drafts of this paper.

Funding This research was supported by the University of Bristol under a University of Bristol Studentship Award.

\section{Compliance with Ethical Standards}

Conflict of Interest The author declares that she has no conflict of interest.

Open Access This article is licensed under a Creative Commons Attribution 4.0 International License, which permits use, sharing, adaptation, distribution and reproduction in any medium or format, as long as you give appropriate credit to the original author(s) and the source, provide a link to the Creative Commons licence, and indicate if changes were made. The images or other third party material in this article are included in the article's Creative Commons licence, unless indicated otherwise in a credit line to the material. If material is not included in the article's Creative Commons licence and your intended use is not permitted by statutory regulation or exceeds the permitted use, you will need to obtain permission directly from the copyright holder. To view a copy of this licence, visit http://creativecommons.org/licenses/by/4.0/.

\section{References}

All-Party Parliamentary Group on Prostitution and the Global Sex Trade (APPG). (2014). Shifting the burden: inquiry to assess the operation of the current legal settlement on prostitution in England and Wales. London: All-Party Parliamentary Group on Prostitution and the Global Sex Trade.

All-Party Parliamentary Group on Prostitution and the Global Sex Trade (APPG). (2018). Behind Closed Doors Organised sexual exploitation in England and Wales. London: All-Party Parliamentary Group on Prostitution and the Global Sex Trade.

Annison, R. (2013). In the dock: examining the UK's criminal justice response to trafficking. London: AntiSlavery International.

Bindel, J., Breslin, R., \& Brown, L. (2013). Capital exploits: a study of prostitution and trafficking in London. London: Eaves for Women.

Brayley, H., \& Cockbain, E. (2014). British children can be trafficked too: towards an inclusive definition of internal child sex trafficking. Child Abuse Review, 23(3), 171-184.

Brooks-Gordon, B. (2005). Clients and commercial sex: Reflections on 'paying the price: a consultation paper on prostitution. Criminal Law Review, 425-443.

Brooks-Gordon, B. (2010). Bellwether citizens: the regulation of male clients of sex workers. Journal of Law and Society, 37(1), 145-170.

Carline, A. (2011a). Constructing the subject of prostitution: a Butlerian Reading of the regulation of sex work. International Journal for the Semiotics of Law, 24(1), 61-78.

Carline, A. (2011b). Criminal justice, extreme pornography and prostitution: protecting women or promoting morality? Sexualities, 14(3), 312-333.

Carline, A. (2012). Of frames, cons and affects: constructing and responding to prostitution and trafficking for sexual exploitation. Feminist Legal Studies, 20(3), 207-225.

Council of Europe (2005). Convention on action against trafficking in human beings. Warsaw: Council of Europe. 
Council of Europe Parliamentary Assembly (2014). Prostitution, trafficking and modern slavery in Europe: Resolution 1983 (2014). Available from: http://www.europarl.europa.eu/sides/getDoc.do?type= TA\&language=EN\&reference=P7-TA-2014-0162 [accessed 6 June 2020].

Coy, M. (Ed.). (2012). Prostitution, harm and gender inequality: theory, research and policy. Farnham: Ashgate.

Crown Prosecution Service. (2017). Violence against women and girls. Crime Report, 2016-2017. London: Crown Prosecution Service.

Crown Prosecution Service (2018). Legal guidance: prostitution and exploitation of prostitution [online], available from: https://www.cps.gov.uk/legal-guidance/prostitution-and-exploitation-prostitution [Accessed 13 October 2019].

Crown Prosecution Service. (2019). Violence against women and girls. Crime Report, 2018-2019. London: Crown Prosecution Service.

Ekberg, G. (2004). The Swedish law that prohibits the purchase of sexual services. Violence Against Women, 10(10), 1187-1218.

European Commission (2016). Report from the Commission to the European Parliament and the Council assessing the impact of existing national law, establishing as a criminal offence the use of services which are the objects of exploitation of trafficking in human beings, on the prevention of trafficking in human beings, in accordance with Article 23 (2) of the Directive 2011/36/EU. Brussels.

European Parliament (2014). Resolution of 26 February 2014 on Sexual Exploitation and Prostitution and its Impact on Gender Equality (2013/2103(INI)). Available from: http://www.europarl.europa.eu/sides/getDoc. do?type=TA\&language=EN\&reference=P7-TA-2014-0162 [accessed 6 June 2020].

European Parliament and European Council, 2011. Directive 2011/36/EU of the European Parliament and of the Council of 5 April 2011 on preventing and combating trafficking in human beings and protecting its victims, and replacing Council Framework Decision 2002/629/JHA.

Farrell, A., Pfeffer, R., \& Bright, K. (2015). Police perceptions of human trafficking. Journal of Crime and Justice, 38(3), 315-333.

Government of the Netherlands (2013). Approach to trafficking in human beings: more focus on minors, prostitution sector and new forms of exploitation required. [press release] 9 October. Available at: http:// www.government.nl/news/2013/09/10/approach-to-trafficking-in-human-beings-more-focus-on-minorsprostitution-sector-and-new-forms-of-exploitation-required.html [Accessed: 17 February 2020].

Great Britain, Northern Ireland Assembly Hansard (2013). Human Trafficking and Exploitation (Further Provisions and Support for Victims) Bill: Second Stage, Vol. 87, No. 5.

Grubb, D., \& Bennett, K. (2012). The readiness of local law enforcement to engage in US anti-trafficking efforts: an assessment of human trafficking training and awareness of local, county, and state law enforcement agencies in the state of Georgia. Police Practice and Research, 13(6), 487-500.

Her Majesty's Government (2011). Human Trafficking: The Government's Strategy.

Her Majesty's Inspectorate of Constabulary (HMIC) (2014). Crime-recording: making the victim count. The final report of an inspection of crime data integrity in police forces in England and Wales. London: HMIC.

Her Majesty's Government and College of Policing (2013). Review of Simple Cautions. London: HM Government and College of Policing.

Hester, M., \& Lilley, S.-J. (2017). Rape investigation and attrition in acquaintance, domestic violence and historical rape cases. Journal of Investigative Psychology and Offender Profiling, 14, 175-188.

Home Office. (2008). Tackling the demand for prostitution: a review. London: Home Office.

Home Office (2010). Circular 006/2010: Provisions in the Policing and Crime Act 2009 that relate to prostitution (sections 14 to 21). London: Home Office.

Home Office (2019). National Referral Mechanism statistics UK: End of year summary 2019: data tables. Available from: https:/www.gov.uk/government/statistics/national-referral-mechanism-statistics-uk-end-ofyear-summary-2019 [accessed 10 June 2020].

House of Commons Home Affairs Select Committee (HASC) (2016). Prostitution. Third Report of Session 2016-17. London.

Hoyle, C., Bosworth, M., \& Dempsey, M. (2011). Labelling the victims of sex trafficking: exploring the borderland between rhetoric and reality. Social \& Legal Studies, 20(3), 313-329.

Independent Anti-Slavery Commissioner (2015) Strategic plan 2015-2017. London: Independent Anti-Slavery Commissioner.

Jones, T., \& Kingshott, B. (2016). A feminist analysis of the American criminal justice system's response to human trafficking. Criminal Justice Studies, 29(3), 272-278.

Keegan, E., \& Yonkova, N. (2018). Stop traffick: tackling demand for sexual services of trafficked women and girls. Social Work and Social Sciences Review, 18(1), 15-30.

Kelly, L., \& Regan, L. (2000). Stopping traffic: exploring the extent of, and responses to trafficking in women for sexual exploitation in the UK. London: Home Office. 
Kelly, L., Coy, M., \& Davenport, R. (2009). Shifting Sands: a comparison of prostitution regimes across nine countries. London: Child \& Woman Abuse Studies Unit (CWASU), London Metropolitan University.

Keren-Paz, T., \& Levenkron, N. (2009). Clients' strict liability towards victims of sex-trafficking. Legal Studies, 29(3), 438-463.

Kingston, S. (2010). Intent to criminalize: Men who buy sex and prostitution policy in the UK. In K. Hardy, S. Kingston, \& T. Sanders (Eds.), New sociologies of sex work (pp. 23-38). Farnham: Ashgate.

Kingston, S., \& Thomas, T. (2014). The police, sex work, and section 14 of the Policing and Crime Act 2009. The Howard Journal of Criminal Justice, 53(3), 255-269.

Kingston, S., \& Thomas, T. (2019). No model in practice: a 'Nordic model' to respond to prostitution? Crime, Law and Social Change, 71, 423-439.

Matolcsi, A. (2017). Section 53A of the Sexual Offences Act 2003 (inserted by section 14 of the Policing and Crime Act 2009) on 'paying for the sexual services of a prostitute subject to coercion etc': Implementation and the views of practitioners. Thesis (PhD). United Kingdom: University of Bristol.

Matthews, R. (2008). Prostitution politics and policy. Oxfordshire: Routledge-Cavendish.

Mulvihill, N. (2014). Gender, power and the making of English prostitution policy. Thesis (PhD). University of Bristol.

Mulvihill, N. (2015). Gender, power, and the translation of English prostitution policy. In N. Aghtaie \& G. Gangoli (Eds.), Understanding gender based violence: national and international contexts (pp. 110-129). Abingdon: Routledge.

Munro, V. (2010). An unholy trinity? Non-consent, coercion and exploitation in contemporary legal responses to sexual violence in England and Wales. Current Legal Problems, 63(1), 45-71.

Munro, V., \& Scoular, J. (2012). Abusing vulnerability? Contemporary law and policy responses to sex work in the UK. Feminist Legal Studies, 20(3), 189-206.

National Police Chiefs' Council (2019). National policing sex work and prostitution guidance. Available from: http://library.college.police.uk/docs/appref/Sex-Work-and-Prostitution-Guidance-Jan-2019.pdf [accessed 9 June 2020].

Niemi, J., \& Aaltonen, J. (2014). Abuse of a victim of sex trade: evaluation of the Finnish sex purchase ban. Helsinki: Ministry of Justice.

O’Connor, M. (2018). Comparative report: disrupt demand. Dublin: Immigrant Council of Ireland.

Office for National Statistics (ONS) (2014). User Guide to Crime Statistics for England and Wales. London: ONS.

Public Administration Select Committee (2014). Caught red-handed: why we can't count on Police Recorded Crime statistics. Thirteenth report of session 2013-14. HC 760. Ldondon: House of Commons Public Administration Select Committee.

Renzetti, C., Bush, A., Castellanos, M., \& Hunt, G. (2015). Does training make a difference? An evaluation of a specialized human trafficking training module for law enforcement officers. Journal of Crime and Justice, 38(3), 334-350.

Ritchie, J., Lewis, J., McNaughton Nicholls, C., \& Ormston, R. (Eds.). (2014). Qualitative research practice: a guide for social science students and researchers (2nd ed.). London: SAGE.

Sanders, T. (2008). Paying for pleasure: men who buy sex. Abindgon: Routledge.

Simmons, J., Legg, C., \& Hosking, R. (2003). National Crime Recording Standard (NCRS): an analysis of the impact on recorded crime. London: Home Office.

UK Ministry of Justice (2018). Freedom of information response. [email] (Personal communication, 8 February).

United Nations (2000). Protocol to prevent, suppress and punish trafficking in persons, Especially Women and Children, Supplementing the United Nations Convention against Transnational Organized Crime. United Nations.

United States Department of State (2018). Trafficking in Persons Report - Germany. US Department of State.

Wagenaar, H., \& Altink, S. (2012). Prostitution as morality politics or why it is exceedingly difficult to design and sustain effective prostitution policy. Sexuality Research \& Social Policy, 9(3), 279-292.

Walby, S., et al. (2016). Study on the gender dimension of trafficking in human beings. Luxembourg: Publications Office of the European Union.

Waltman, M. (2011). Sweden's prohibition of purchase of sex: the law's reasons, impact, and potential. Women's Studies International Forum, 34(5), 449-474.

Westmarland, N. (2006). From the personal to the political: shifting perspectives on street prostitution in England and Wales. In G. Gangoli \& N. Westmarland (Eds.), International approaches to prostitution. Law and policy in Europe and Asia (pp. 21-43). Bristol: Policy Press.

Westmarland, L. (2009). Gender abuse and people trafficking. In J. Muncie, D. Talbot, \& R. Walters (Eds.), Crime: local and global (pp. 105-136). Devon: Willan/The Open University.

Westmarland, N., Johnson, K., \& McGlynn, C. (2018). Under the radar: the widespread use of 'out of court resolutions' in policing domestic violence and abuse in the United Kingdom. British Journal of Criminology, $58(1), 1-16$. 
Zimmerman, C., Hossain, M., Yun, K., Roche, B., Morison, L., \& Watts, C. (2006). Stolen smiles: report on the physical and psychological health consequences of women and adolescents trafficked in Europe. London: The London School of Hygiene and Tropical Medicine.

Publisher's Note Springer Nature remains neutral with regard to jurisdictional claims in published maps and institutional affiliations. 